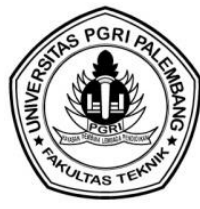

\title{
PEMANFAATAN BATUBARA PERINGKAT HVCBITUMINUS SEBAGAI BAHAN BAKU INDUSTRI KIMIA DAN INDUSTRI PETROKIMIA
}

\author{
Ratih Diah Andayani \\ Dosen Fakultas Teknik,Universitas IBA \\ email : ratihd.andayani@gmail.com
}

\begin{abstract}
ABSTRAK
Batubara selain digunakan sebagai bahan bakar, juga dapat digunakan sebagai bahan baku idustri kimia dan industri petrokimia melalui proses pirolisis. Tar merupakan produk cair hasil pirolisis batubara yangkaya akan senyawa hidrokarbon aromatik, di antaranya BTX, PCX yang diperlukan pada industri kimia dan petrokimia. Penelitian ini bertujuan untuk mengkaji pemanfaatan batubara sebagai bahan baku alternatif pada industri kimia dan petrokimia.Penelitian dilakukan dengan memvariasikan temperatur pirolisis pada $400,500,600$ dan $700{ }^{\circ} \mathrm{C}$. Batubara yang digunakan peringkat HVC- Bituminus berasal dari daerah penambangan Berau Kalimantan Timur dengan ukuran partikel -4/10 mesh. Gas inert yang digunakan gas Nitrogen dengan laju alir $300 \mathrm{~mL} / \mathrm{menit}$. Tar hasil proses pirolisis di distilasi berdasarkan perbedaan titik didihnya menjadi empat fraksi. Hasil penelitian menunjukkan bahwa Temperatur pirolisis berpengaruh terhadap perolehan kuantias produk distilat tar, semakin tinggi temperatur pirolisis, produk distilat fraksi minyak ringan (BTX) dan residu menunjukkan kecenderangan meningkat, sementara fraksi minyak tengah (PCX), fraksi minyak berat dan fraksi minyak antrasena menunjukan kecenderungan yang sebaliknya. Produk fraksi minyak ringan yang diduga mengandung senyawa BTX mencapai maksimum pada temperatur pirolisis $600^{\circ} \mathrm{C}$ sebesar 22,9 g/kg Batubara, sedangkan produk fraksi minyak tengah yang diduga mengandung senyawa PCX, fraksi minyak berat dan fraksi minyak antrasena mencapai maksimum pada temperatur $400^{\circ} \mathrm{C}$ masing-masing sebesar $13,9 \mathrm{~g} / \mathrm{kg}$ batubara, $15,3 \mathrm{~g} / \mathrm{kg}$ batubara dan 22,3 g/kg Batubara.
\end{abstract}

Kata kunci : Pirolisis, Tar, BTX,PCX

\section{PENDAHULUAN}

Cadangan batubara di Indonesia pada tahun 2018 tercatat sebesar 26,2 miliar ton, selain itu masih ada potensi cadangan yang belum terjamah yang jumlahnya mencapai 124,6 miliar ton, dengan rata-rata produksi sebesar 461 ton per tahun berarti cadangan batubara yang ada sekarang cukup untuk memenuhi kebutuhan dalam negeridan untuk ekspor sampai 56 tahun ke depan (Safyra Primadhyta,2018)

Sampai saat ini ,pemanfaatan batubara di Indonesia masih terbatas hanya sebagai bahan bakar padat langsung (direct combustion) pada industri semen, PLTU,industri kecil dan rumah tangga serta keperluan ekspor, padahal selain itu, batubara juga dapat dimanfaatkansebagai bahan baku pada industri kimia dan petrokimia, mengingat komponen di dalam batubara kaya dengan senyawa senyawa hidrokarbon aromatik seperti benzena, Toluena, Xilena (BTX) serta Phenol, Cresol dan Xilenol (PCX) dan lain lain. Senyawa-senyawa tersebut banyak digunakan sebagai bahan baku industri kimia dan petrokimia.Untuk mendapatkan produk BTX dan PCX perlu suatu teknologi pengolahan dan penanganan batubara tersebut sehingga didapat fraksi senyawa hidrokarbon aromatik cair berdasarkan perbedaan titik didihnya. 
Sampai saat ini Indonesia belum menerapkan teknologi pemanfaatan batubara seperti di negara-negara maju lainnya, ketergantungan akan minyak bumi masih medominasi baik untuk keperluan bahan bakar maupun untuk memenehui bahan baku kimia dan petrokimia tetapi diharapkan dimasa mendatang dapat mengembangkan teknologi pemanfaatan batubara mengingat harga minyak bumi yang semakin naik dan jumlah cadangan minyak bumi yang semakin menipis.

Salah satu teknologi pemanfaatan batubara yang cukup potensial untuk dikembangkan adalah proses pirolisis, pada proses ini, batubara dapat diubah menjadi produk cair, gas dan padat (char). Produk gas dapat digunakan sebagai bahan bakar gas, sedangkan produk cairnya berpotensi untuk bahan baku industri kimia dan petrokimia. Pencairan batubara peringkat rendah sampai sedang apabila dilakukan dengan proses pirolisis $\mathrm{b}$ akan kita dapatkan gas metana yang lebih banyak dibandingkan kelas tinggi selain itu arang yang dihasilkan dapat dibentuk menjadi kokas untuk pembriketan yang berguna untuk kebutuhan rumah tangga serta industri kecil sampai menengah ( Sodikin, M.P, 2011). Batubara Bituminusmerupakan jenis batubara peringkat tinggi,dan mempunyai kualitas yang baik serta mengandung zat terbang (volatile matter) tinggi, sehingga apabila dilakukan pirolisis akan menghasilkan produk cair dan char yang tinggi sedangkan produk gas rendah.

Beberapa hasil penelitian mendapatkan konsentrasi hidrokarbon aromatik yang berbeda untuk setiap suhu pirolisis, untuk itu perlu suatu penelitian yang dapat memberikan informasi pada temperatur pirolisis berapa dapat memberikan kuantitas dan kualitas konsentrasi produk yang diperlukan.

Tujuan dari penelitian ini adalah mengkaji pemanfaatan batubara sebagai bahan baku alternatif pada industri kimia dan industri petrokimia. Penelitian dilakukan dengan memvariasikan temperatur pirolisis pada 400, 500, 600 dan $700{ }^{\circ} \mathrm{C}$ untuk mendapatkankuantitas dan kualitas konsentrasi senyawa hidrokarbon aromatik cair yang dapat dimanfaatkan sebagai bahan baku industri kimia dan petrokimia. Batubara yang digunakan peringkat - Bituminus berasal dari daerah penambangan Berau Kalimantan Timur.

\section{TINJAUAN PUSTAKA}

Batubara merupakan bahan bakar fosil padat yang terbentuk dari sisa tumbuh-tumbuhan yang tertimbun dalam waktu yang sangat lama dengan melalui beberapa fasa geologi, kemudian karena pengaruh panas serta tekanan terjadi perubahan kimia menjadi batubara, tahapan pembentukan batubara dimulai dari kayu kemudian gambut, lignit, sub-bituminus, bituminus dan antrasit. Komponen utama pembentuk batubara adalah $\mathrm{C}, \mathrm{H}$ dan $\mathrm{O}$ yang membentuk maseral dan sejumlah kecil unsur anorganik, air dan gas yang terperangkap di dalam pori-porinya. Selama proses pembentukan batubara terjadi penurunan kadar oksigen dan kadar zat terbang, sementara kadar hidrogen relatif konstan dan kadar karbon meningkat. Kadar oksigen sebanyak $30 \%$ sampai $50 \%$ di dalam tumbuh-tumbuhan berkurang menjadi $20 \%$ - $25 \%$ untuk batubara lignit, $20 \%$ - $25 \%$ untuk batubara sub-bituminus, $5 \%-10 \%$ untuk batubara Bituminus dan sekitar $1 \%$ untuk Batubara Antrasit.

Struktur kimia batubara sulit ditentukan karena sangat komplek, Batubara tersusun dari grupgrup polisiklik dan aromatik, masing-masing grup dihubungkan oleh struktur alifatik. Gugus polisiklik terdiri dari gugus fungsional oksigen, nitrogen dan sulfur (Shinn, 1984). Aromatisitas karbon meningkat dengan kenaikan peringkat batubara yakni 0,66 untuk batubara peringkat lignit, 0,70 untuk batubara sub-bituminus, 0,78-0,88 untuk batubara Bituminus dan 0,99 untuk batubara antrasit. Sedangkan jumlah cincin aromatik bertambah dengan semakin tinggi kadar karbon dalam batubara, sementara kereaktifan batubara berkurang dengan bertambahnya jumlah cincin aromatik (Tsai, 1982) 
Tar merupakan produk cair batubara melalui proses liquifaksi atau proses pirolisis, tar sebagian besar tersusun dari campuran senyawa hidrokarbon dengan berat molekul rata-rata 200 sampai 1200 (Gavalas, 1982).,sementara (Finn ,1980) mengemukakan bahwa tar sebagian besar terdiri dari material padat yang terdispersi dalam keadaan koloid. Senyawa hidrokarbon yang terkandung di dalam tar terdiri dari senyawa hidrokarbon aromatik di antaranya Benzena, Toulena, Xilena, Phenol, Cresol dan Xilenol. Senyawa-senyawa tersebut diperlukan sebagai bahan baku industri kimia, seperti karet sintetis, polimer, obat-obatan, pelarut, grafit dan coating antaranya benzena dan naphthalene yang digunakan sebagai bahan dasar industri polimer seperti plastik.

Berdasarkan perbedaan titik didih senyawa-senyawa aromatik yang terkandung di dalam tar, dibedakan menjadi empat fraksi, yaitu

- Fraksi minyak ringan (light oil) ; titik didih $<200 \mathrm{C}$, terdiri dari senyawa parafin, naftena dan senyawa aromatik ringan BTX (Benzena, Toluena dan Xilena)

- Fraksi minyak tengah (middle oil); titik didih $200-300{ }^{\circ} \mathrm{C}$, sebagian besar terdiri dari senyawa PCX (Phenol Cresol dan Xilenol)

- Fraksi minyak berat (heavy oil), titik didih $250-300^{\circ} \mathrm{C}$, sebagian besar terdiri atas senyawa diaromatik antara lain naftalen dan trifenil.

- Fraksi minyak antrasena(antracena oil), titik didih $300-350{ }^{\circ} \mathrm{C}$

- Residu (pitch), titik didih $>350^{\circ} \mathrm{C}$, sebagian besar terdiri atas karbon, minyak berat dan lilin merah

( David, dkk, 1984) dengan menggunakan batubara jenis brown coal Yallourn (VM 50,3\% daf) mengatakan bahwa produk tar mencapai maksimum pada temperatur $600{ }^{\circ} \mathrm{C}$ dengan kuantitas $19 \%$ sementara bahwa makin tinggi temperatur pirolisis, produk tar meningkat dan mencapai maksimum pada rentang temperatur sekitar $550-600{ }^{\circ} \mathrm{C}$.

(Kaiser, 1984) meneliti pengaruh temperatur pirolisis terhadap pembentukan produk BTX dengan menggunakan batubara sub-bituminus, produk BTX meningkat dengan kenaikan suhu pirolisis dan mencapai maksimum pada temperatur sekitar $800^{\circ} \mathrm{C}$.

(Xu dan Tomitu, 1989) dengan menggunakan batubara peringkat Bituminus (VM 33,3\% daf) meneliti pengaruh temperatur terhadap komposisi hidrokarbon cair dan hasilnya menunjukkan bahwa senyawa aromatik PCX (Phenol, Cresol dan Xilenol) terbentuk pada temperatur rendah yaitu pada temperatur $500{ }^{\circ} \mathrm{C}-700{ }^{\circ} \mathrm{C}$ dan mencapai maksimum pada temperatur $600{ }^{\circ} \mathrm{C}$, di atas temperatur tersebut cenderung menurun, sementara BTX (Benzena, Toluena dan Xilena) terbentuk pada temperatur relatif lebih tinggi yaitu pada tempeartur $700-900{ }^{\circ} \mathrm{C}$, diantaranya benzena hasilnya meningkat terus sampai temperatur $900{ }^{\circ} \mathrm{C}$, sementara Toluena mencapai maksimum pada temperatur $800{ }^{\circ} \mathrm{C}$ dan xilena konstan sampai temperatur $800^{\circ} \mathrm{C}$.

Konsep termodinamika diperlukan untuk menganalisis konversi maksimum yang dapat dicapai dan banyaknya kalor yang terlibat dalam reaksi pembentukan produk. Reaksi pirolisis batubara adalah merupakan reaksi penurunan energi bebas, konsep termodinamika diperlukan untuk menentukan kekuatan ikatan antara $\mathrm{C}-\mathrm{C}$ dan $\mathrm{C}-\mathrm{H}$ gugus alifatik dan $\mathrm{C}-\mathrm{C}$ dan $\mathrm{C}-\mathrm{H}$ pada gugus aromatik yang dapat dibandingkan dari harga energi bebas yang menyertai reaksi pembentukan dan pemutusan ikatan. Hal ini diperlukan untuk memperkirakan kemungkinan terjadinya pemutusan ikatan yang terlebih dahulu antara ikatan-ikatan pada gugus alifatik dan gugus aromatik. Harga perubahan bebas ikatan alifatik dan harga energi bebas resonansi senyawa aromatik masing masing tertera pada Tabel 1. dan Tabel 2. 
Tabel 1. Harga Perubahan Energi Bebas $\left(\Delta \mathrm{F}^{\circ}\right)$ Pemisahan Ikatan Alifatik

\begin{tabular}{|c|c|c|c|c|}
\hline \multirow{2}{*}{ Temperatur (K) } & \multicolumn{4}{|c|}{ Energi Bebas (kal/g.K) } \\
\cline { 2 - 5 } & $\mathrm{C}-\mathrm{H}$ & $\mathrm{C}-\mathrm{C}$ & $\mathrm{C}-\mathrm{CH}_{3}$ & $\mathrm{C}=\mathrm{C}$ \\
\hline $\mathbf{6 0 0}$ & 1.281 & -12.395 & -8.477 & -23.460 \\
\hline $\mathbf{7 0 0}$ & 652 & -13.904 & -11.372 & $-22 / 940$ \\
\hline $\mathbf{8 0 0}$ & 42 & -15.459 & -15.276 & -22.433 \\
\hline $\mathbf{9 0 0}$ & -571 & -17.058 & -18.700 & -21.942 \\
\hline $\mathbf{1 0 0 0}$ & -1.178 & -18.120 & -22.120 & -21.462 \\
\hline
\end{tabular}

Tabel 2. Harga Perubahan Energi Bebas $\left(\Delta \mathrm{F}^{\circ}\right)$ Pemisahan Ikatan Alifatik

\begin{tabular}{|c|c|c|c|c|c|c|}
\hline \multirow{2}{*}{$\begin{array}{c}\text { Temperatur } \\
(\mathrm{K})\end{array}$} & & \multicolumn{4}{|c|}{ Energi Bebas (kal/g.K) } & \\
\cline { 2 - 7 } & Benzena & Toluena & Xilena & Naftalena & Antrasena A & Antrasena B \\
\hline $\mathbf{6 0 0}$ & 55.770 & 64.300 & 78.780 & 110.760 & 156.620 & 167.050 \\
\hline $\mathbf{7 0 0}$ & 57.520 & 66.480 & 84.000 & 114.760 & 166.630 & 173.300 \\
\hline $\mathbf{8 0 0}$ & 59.610 & 69.000 & 89.280 & 118.880 & 177.040 & 178.800 \\
\hline $\mathbf{9 0 0}$ & 61.610 & 71.460 & 94.570 & 123.150 & 186.430 & 185.020 \\
\hline $\mathbf{1 0 0 0}$ & 64.720 & 73.830 & 99.820 & 127.540 & 198.990 & 191.440 \\
\hline
\end{tabular}

Berdasarkan harga energi bebas yang tertera pada Tabel 1 mengindikasikanbahwa pada proses pirolisis batubara ikatan yang pertama kali putus adalah ikatan alifatik $\mathrm{C}=\mathrm{C}$, kemudian disusul ikatan $\mathrm{C}-\mathrm{C}$, ikatan $\mathrm{C}-\mathrm{CH}_{3}$ dan yang terakhir ikatan $\mathrm{C}-\mathrm{CH}_{3}$. Jika dibandingkan harga energi bebas yang tertera pada Tabel 1 dan tabel 2, memberi petunjuk bahwa ikatan aromatik lebih sulit putus dibandingkan dengan ikatan alifatik, hal ini disebabkan karena adanya fenomena resonansi pada iakatan aromatik sehingga ikatan antara C-C aromatik sangat stabil.

\section{METODE PENELITIAN}

Produk cair (tar) merupakan hasil proses pirolisis batubara peringkat Bituminus berasal dari PT. Indo Menco mandiri Blok barat kalimantan Timur dengan ukuran partikel tetap yaitu -4/10 mesh, gas inert yang digunakan adalah gas Nitrogen dengan laju alir tetap yaitu $300 \mathrm{~mL} / \mathrm{menit}$.

Penelitian dilakukan dalam skala laboratorium yang dilaksanakan di laboratorium Fakultas Teknik Universitas IBA Palembang dengan menggunakan produk tar sebanyak $100 \mathrm{~mL}$ sebagai hasil proses pirolisis pada suhu $400,500,600$ dan $700{ }^{\circ} \mathrm{C}$.

Produk tar hasil prolisis dipisahkan menjadi empat fraksi berdasarkan perbedaan titik didihnya dengan distilasi menurut ASTM D86-12. Proses distilasi dilakukan di dalam labu distilasi standard $200 \mathrm{~mL}$. Labu distilasi dilengkapi dengan termometer dan pipa saluram uap. Labu distilasi disangga dengan kaki tiga yang dilapisi dengan kassa asbes. Kondensor yang digunakan untuk mengembunkan uap digunakan tipe pipa ganda dengan diamater pipa luar 14,29 $\mathrm{mm}$ dan panjang 55,88 cmyang dipasang dengan kemiringan $75^{\circ}$. Sebagai media pendingin digunakan air es (suhu $4,4{ }^{\circ} \mathrm{C}$ ) untuk fraksi-1dan fraksi-2, untuk fraksi-2 digunakan air pada suhu kamar dan fraksi-4 sebagai pendingin digunakan air dengan suhu $40{ }^{\circ} \mathrm{C}$.

\section{Prosedur Penelitian}

Seratus $\mathrm{mL}$ tar di masukkan ke dalam labu distilasi, kemudian dipanaskan dengan menggunakan pembakar LPG. Pembacaan dan pencatatan kenaikan suhu dan volume distilat dilakukan setiap kenaikan suhu $5{ }^{\circ} \mathrm{C}$. laju pemanasan diatur sehingga laju uap yang mengembun sebagai hasil distilat sekitar 4-5 mL per menit. Hasil distilasi ditampung dalam gelas ukur untuk 
diukur volumenya dan ditimbang dengan neraca analitis kemudian dimasukkan ke dalam botol sampel. Rangkaian peralatan distilasi dan dimensi labu distilasi disajikan pada Gambar 1

\section{HASIL DAN PEMBAHASAN}

Batubara yang digunakan pada penelitian ini berperingkat HVC-Bituminus mempunyai kandungan zat terbang yang cukup tinggi dengan kandungan air rendah. Analisa proksimat dan ultimat dari batubara sesuai dngan ASTM D-388-77disajikan pada Tabel 3

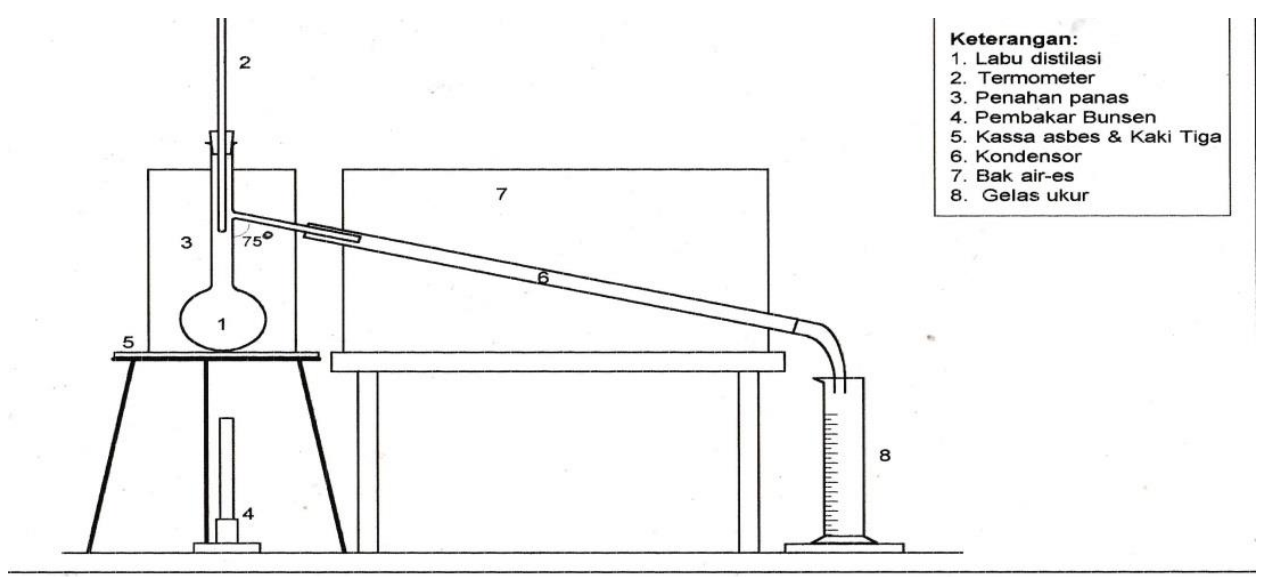

Gambar 1 : Rangkaian Peralatan Distilasi Tar

Tabel 3 : Analisa Proksimat dan Ultimat Batubara HVC-Bituminus

\begin{tabular}{|c|l|c|l|c|}
\hline No & \multicolumn{2}{|l|}{ Analisa Proksimat \% -adb) } & \multicolumn{2}{l|}{ Analisa Ultimat $(\%$-adb) } \\
\hline 1 & Kand. Air & 6,9 & Total belerang & 2,92 \\
\hline 2 & Abu & 2,41 & Karbon & 68,30 \\
\hline 3 & Kadar zat terbang & 42,80 & Hidrogen & 6,51 \\
\hline 4 & Karbon tetap kalor & 47,95 & Nitrogen & 1,03 \\
\hline 5 & $\begin{array}{l}\text { Nilai } \\
\text { (cal/g/adb) }\end{array}$ & Oksigen & 18,83 \\
\hline
\end{tabular}

Komposisi tar dibedakan berdasarkan perbedaan titik didihnya menjadi empat fraksi.Hasil distilasi tar pada temperatur $<200{ }^{\circ} \mathrm{C}$ merupakan fraksi-1. Fraksi ini mengembun pertama kali pada pada suhu sekitar $80{ }^{\circ} \mathrm{C}$ merupakan cairan yang mula-mula berwarna kuning dan apabila dibiarkan lama di udara berubah menjadi coklat. Hasil distilat yang mengembun pada temperatur $200-250{ }^{\circ} \mathrm{C}$ merupakan produk fraksi-2, berupa cairan berwarna coklat muda, sedangkan produk fraksi-3 maengembun pada suhu $250-300{ }^{\circ} \mathrm{C}$ merupakan cairan berwarna coklat tua, dn fraksi-4 berwarna coklat kehitaman dan lebih kental dibandingkan dengan fraksi-1. Fraksi-2 dan fraksi-3 dan sisa yang tertinggal di labu ditilasi merupakan residu yang berupa material padat yang kenyal dan berwarna hitam.

Hasil penelitian distilasi tar hasil pirolisis batubara Bituminus pada berbagai temperatur dapat dilihat pada Tabel 4 dan dialurkan pada Gambar 1. 
Tabel 4 : Hasil Percobaan Distilasi Produk Tar Pirolisis Batubara Bituminus

\begin{tabular}{|l|c|c|c|c|}
\hline \multirow{2}{*}{ Produk } & \multicolumn{4}{|c|}{ Produk Distilat (g/kg umpan Batubara) } \\
\cline { 2 - 5 } & 400 & 500 & 600 & 700 \\
\hline Fraksi-1 & 11,19 & 16,32 & 22,90 & 18,69 \\
\hline Fraksi-2 & 13,87 & 13,75 & 13,00 & 9,11 \\
\hline Fraksi-3 & 15,33 & 11.19 & 10,52 & 6,27 \\
\hline Fraksi-4 & 22,26 & 17.91 & 19,19 & 14,55 \\
\hline Residu & 18,25 & 26,02 & 50,91 & 52,76 \\
\hline Zat Terlarut & 36,26 & 49.02 & 43,79 & 24,37 \\
\hline Total & 117,16 & 134,20 & 160,32 & 125,76 \\
\hline
\end{tabular}
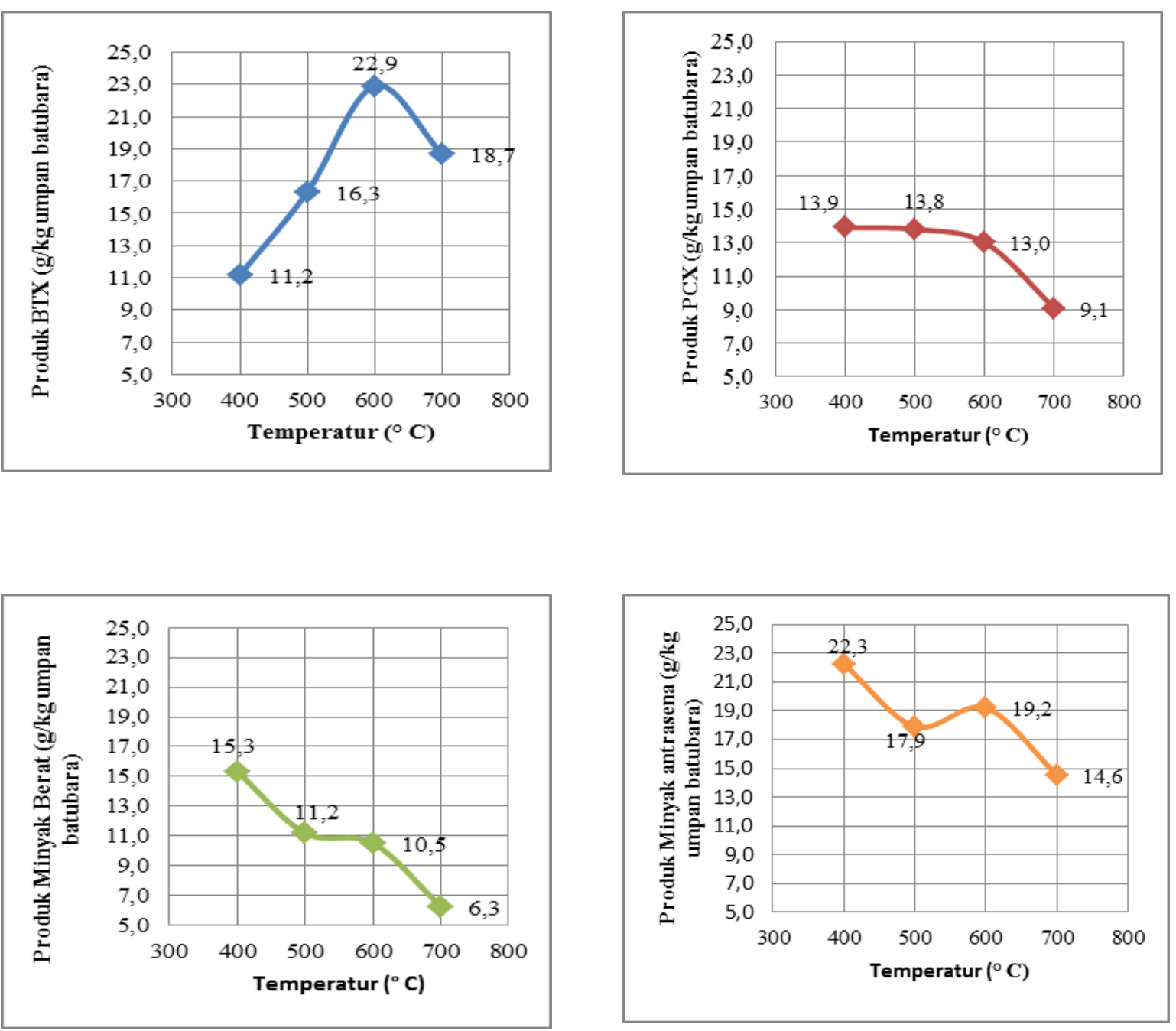

Gambar 2: Kurva Pengaruh Temperatur Terhadap Komposisi Produk Hidrokarbon Cair Distilasi Tar Hasil Pirolisis Batubara HVC Bituminus 


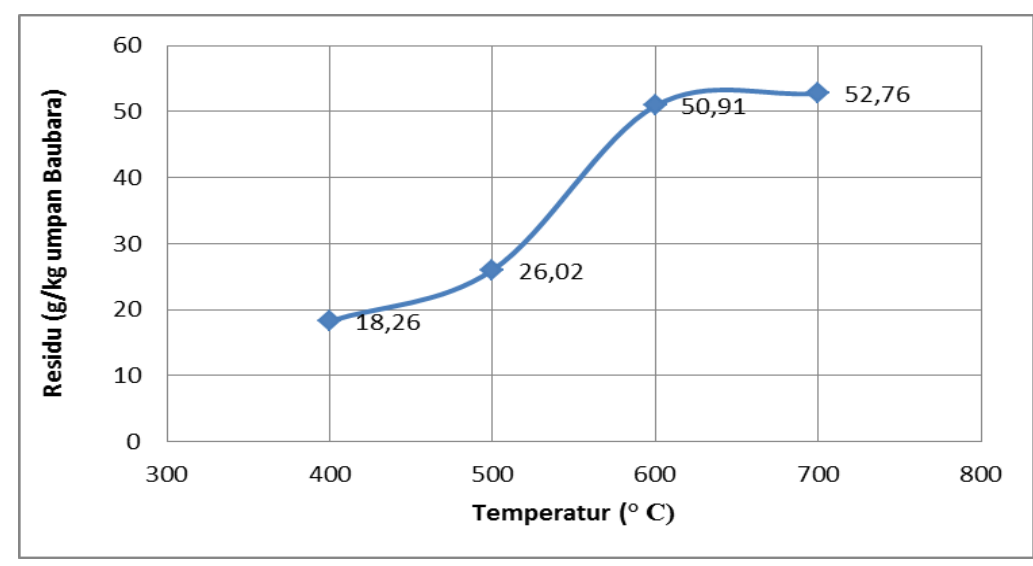

Gambar 3 : Kurva Pengaruh Temperatur Terhadap Produk Residu Distilasi Tar Hasil Pirolisis Batubara HVC Bituminus

Pada Gambar 2 dan Gambar 3, dapat dilihat bahwa perolehan fraksi minyak ringan (BTX) menunjukkan kecenderung meningkat dengan bertambah tinggi temperatur pirolisis dan mencapai maksimum pada temperatur $600^{\circ} \mathrm{C}$ yaitu sebesar $22,9 \mathrm{~g} / \mathrm{kg}$ umpan batubara, dan pada temperatur $700^{\circ} \mathrm{C}$ menunjukkan kecenderung menurun, sedangkan fraksi minyak tengah (PCX), fraksi minyak berat dan fraksi minyak antrasena menunjukkan kecenderungan menurun dengan kenaikan temperatur, sementara residu terlihat selalu meningkat dengan naiknya temperatur.

Peningkatan hasil fraksi-1 dengan kenaikan tempeartur pirolisis menujukkan bahwa senyawasenyawa fraksi-1 sebagian besar terbentuk pada temperatur realitif lebih tinggi. Hal ini memberi arti bahwa senyawa-senyawa tersebut sulit sekali terbentuk pada temperatur rendah terutama dari dekomposisi batubara karena adanya fenomena resonansi pada ikatan aromatik sehingga ikatan antara $\mathrm{C}-\mathrm{C}$ aromatik sangat stabil dan hanya dapat diputuskan pada temperatur yang relatif tinggi. Fenomena ini menimbulkan dugaan bahwa produk BTXdan residu sebagian besar terbentuk karena pemecahan dari senyawa aromatik yang lebih besar, di antaranya PCX, minyak berat dan minyak antrasena, senyawa antrasena melalui serangkaian reaksi yang sangat kompleks karena senyawa-senyawa ini, mempunyai energi bebas yang lebih besar sehingga untuk memutuskan ikatan $\mathrm{C}=\mathrm{C}$ aromatik diperlukan panas yang tinggi. Senyawa- senyawa aromatik yang lebih besar sebagian terjadi pemecahan ikatan membentuk senyawa-senyawa aromatik yang lebih sederhana dan sebagianterjadi reaksi penggabungan melalui reaksi polimerisasi membentuk molekul aromatik yang lebih besar sebagai residu.

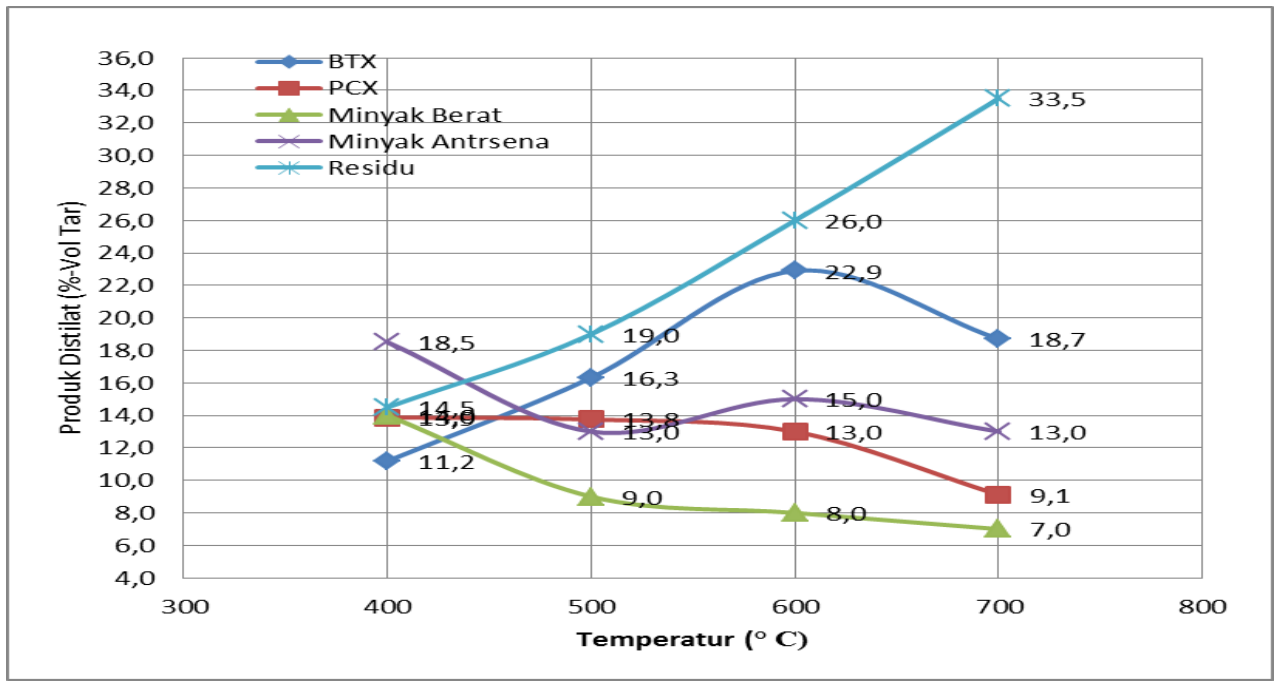




\section{Gambar 4 : Kurva Pengaruh Temperatur Pirolisis Terhadap Produk Distilat Tar}

Jika dilihat secara keseluruhan (Gambar-4) perolehan yang tertinggi adalah residu, kemudian disusul produk BTX, sementara produk PCX dan Minyak antrasena hampir sama dan produk yang paling rendah adalah minyak berat.

Pirolisis pada temperatur rendah $\left(400{ }^{\circ} \mathrm{C}\right)$ menunjukkan produk yang terbesar terbentuk adalah Produk minyak antrasena dan produk yang terendah adalah BTX, tetapi dengan kenaikkan temperatur kecenderungan berubah, produk BTX menunjukkan peningkatan hingga temperatur $600{ }^{\circ} \mathrm{C}$, residu terus menunjukkan peningkatan hingga temperatur $700{ }^{\circ} \mathrm{C}$, sementara produk PCX, minyak berat dan minyak antrasena cenderung menurun. Kecenderungan ini mengindikasikan bahwa pada Senyawa BTX terbentuk pada temperatur tinggi sebagai produk dekomposisi dari senyawa aromatik yang lebih komplek.

Dengan kenaikan temperatur,maka terjadireaksi sekunder yang meliputi perengkahan, kondensasi dan polimerisasi produk zat terbang primer menjadi senyawa lain.Pada suhu $>500{ }^{\circ} \mathrm{C}$ pada struktur senyawa hidrokarbon zat terbang terengkah menjadi karbon dan gas, senyawa parafin rantai panjang terengkah menjadi senyawa parafin yang lebih sederhana dan olefin. Pada tempeartur > $600{ }^{\circ} \mathrm{C}$ terjadi kondensasi senyawa olefin membentuk senyawa molekul yang lebih besar seperti naftalena, selanjutnya naftalena terdekomposisi menjadi senyawa aromatik, jika senyawa aromatik yang terbentuk mempunyai rantai samping alifatik, pada pemanasan lebih lanjut terdekomposisi menjadi senyawa olefin dan aromatik ringan (benzena) atau senyawa aromatik dengan rantai samping yang lebih sederhana (Xilena).

(Cypres ,1981) bahwa pada reaksi sekunder meningkatkan produk gas dan minyak ringan seperti BTX dengan menekan produk PCX, sementara (Finn, 1980) mengamati hidropirolisis batubara jenis hvc bituminus, menyatakan bahwa produk benzena sebagian merupakan produk dari perengkahan senyawa aromatik inti banyak.

\section{KESIMPULAN}

- Temperatur pirolisis berpengaruh terhadap produk distilat tar, semakin tinggi temperatur pirolisis, produk BTX dan residu menunjukkan kecenderangan meningkat, sementara produk PCX, minyak berat dan minyak antrasena menunjukan kecenderungan yang sebaliknya.

- Produk BTX mencapai maksimum pada temperatur pirolisis $600^{\circ} \mathrm{C}$ sebesar $22,9 \mathrm{~g} / \mathrm{kg}$ Batubara, sedangkan produk PCX, minyak berat dan minyak antrasena mencapai maksimum pada temperatur $400^{\circ} \mathrm{C}$ masing-masing sebesar 13,9 g/kg batubara, 15,3 g/kg batubara dan 22,3 g/kg Batubara.

\section{DAFTAR PUSTAKA}

ASTM D388-77, ;American Society For Testing and Material; Part 26, PA, 1986

ASTM D86-12, Standard Test Method for Distillation of Petroleum Product Fraction atAsmosphere, ASTM International, West Conshohocken,PA,2012

Cypres R,.and Furfary S; Fixed-bed Pyrolysis of Coal under Hydrogen Pressure at Low HeatingRate; Fuel, Vol.60, September, hal 768-778, 1980.

David I.C. dkk; Product From Rapid Heating of a Brown Coal in the Temperature Range 400- 2300

${ }^{\circ} \mathrm{C}$, Fuel, vol.63, 1984, hal.394-400. 
Finn J.M, dkk; Light Aromatics from the Hydropyrolysisi of Coal ; Fuel, Vol.59, Juni, 1980, hal.397404.

Gavalas G.R; Coal Pyrolysis, Coal Science and Technology 4, Elsevier Scietific Publishing Co, New York, 1982.

Kaiser M,.dkk; Kinetics of Primary and Secondary Reaction and Hydropyrolysis at HighHeating Constitution of Coal; Fuel, vol.63, Juni 1984, hal.731-737.

Safyra Primadhyta, CNN Indonesia; Indonesia Punya Cadangan Batubara 26,2 Miliar Ton. http://m.cnnindonesia.com.diakses23 Mei 2018.

Shinn, J.H; From Coal to Single-Stage and Two-StageProduct : a Reactive Model of CoalStructure; Fuel, Vol. 63, 1984.

Sodikin M.P; Teknologi Pemanfaatan Batubara UntukMenghasilkan Batubara Cair, Pembangkit tenaga Listrik, Gas Metana Dan Briket Batubara; Prosiding Seminar Nasional AvoER ke-3, Palembang, 26-27 Oktober 2011.

Tsai S.C; Fundamental of Coal Benefication and Utilization; Elsevier Scientific Publishing Co, New York, 1982.

Xu W.C, dan Tomita A; The Effects of Temperature and Residance Time on the SecondaryReaction of Volatiles from Coal Pyrolysis; Fuel Processing Technology, Vol.21, 1989. 